DOI https://doi.org/10.18551/rjoas.2017-09.35

\title{
CONTAMINATION OF COLIFORM, ESCHERICHIA COLI, AND LEAD IN VEGETABLES SOLD AT TRADITIONAL MARKET IN PALEMBANG CITY PROVINCE OF SOUTH SUMATRA
}

\author{
Yani Ade Vera*, Hasbi, Priyanto Gatot, Pambayun Rindit, Wijaya Agus \\ Faculty of Agriculture, University of Sriwijaya, Indonesia \\ *E-mail adeverayani@yahoo.com
}

\begin{abstract}
This study aims to identify the number of contaminantion of coliform, Escherichia coli and lead contained in lettuce, tomato and carrots at the level of traditional market in Palembang city. There were 27 total samples selected from four traditional markets. Microbial analysis was determine based on AOAC (1984) method, lead analysis by using AAS (Shimatzu type AA 700). The data were expressed as mean \pm standard deviation was calculated using Microsoft Excel 2007 program. All research work conducted in triplicate. The results showed that all vegetables contained coliform and lead contamination while Escherichia coli was not detected.
\end{abstract}

\section{KEY WORDS}

Coliform, Escherichia coli, plumbun, lettuce, tomato, carrot.

Currently consumption of fresh vegetables is increasing. The Food and Drug Administration (FDA) and the World Health Organization (WHO) recommends consuming 5-9 servings of vegetables daily because it can reduce the risk of certain diseases (Weldezgina and Muleta, 2016; Ignarro et al., 2007; Liu, 2003). Lettuce, tomatoes, and carrots are vegetables that are often consumed fresh (raw).

Although it has health benefits, raw vegetables need to be taken into consideration of their safety level because it is suspected that vegetables have been contaminated due to improper treatment at all stages during pre and post harvest techniques (De Roever, 1999; Lund et al., 2000; Amoah et al., 2006). Types of contaminants commonly found ini vegetables include pathogenic microbial contaminants and chemical contaminants.

Many epidemics in many countries are caused by the consumption of fresh vegetables contaminated with microbes (Beuchat, 2002; FAOMHO, 2008). Pathogenic microbes commonly detected in fresh vegetables are coliform bacteria and Escherichia coli (Tambekar and Mundhada, 2006).

In developing countries, the use of waste water and fertilizers for vegetable production is a contributing factor to the contamination of vegetables (Johannessen et al., 2002; AdeOluwa and Cofie, 2012). Coliform is used as an indicator of microbiological quality of water and food (Chaturvedi et al., 2013). The presence of coliform contamination in vegetables indicates that vegetables are contaminated by human and animal feces (Cornish et al., 1999). Microbiological contamination of pathogens originating from irrigation water contaminated with waste, soil or manure used as fertilizer characterized by the presence of Escherichia coli (Purba et al., 2012).

Several studies have revealed the presence of pathogenic microbial contamination in vegetables that harm consumers (D'Mello, 2003; Zandstra and De Kryger, 2007). In the USA there is an outbreak of E.coli O157: $\mathrm{H} 7$ contained on the lettuce from the Taco Bell restaurant in the northern United States (CDC, 2015).

The International Commission on Microbiological Specification for Foods (ICMSF) (1996) recommends vegetables to be consumed raw containing Escherichia coli less than $10^{3} \mathrm{CFU} / \mathrm{g}$. Directorate General of Food and Drug Control of the Republic of Indonesia (1989), requires maximum consumed vegetables containing Escherichia coli $10^{2} \mathrm{CFU} / \mathrm{g}$.

Contaminants of other harmful chemicals found in vegetables are heavy metals such as lead $(\mathrm{Pb})$ which pollute many environments and are harmful to human health 
(Widaningrum et al., 2007; Notohadiprawiro, 1995). The source of heavy metal contaminants comes from excessive exhaust fumes, fertilizers or pesticides that exceeds the prescribed safe dose (Singh, 2004). Winarti and Miskiyah (2010), showed that the content of lead contaminats $(\mathrm{Pb})$ in carrots was $0.10-0.21 \mathrm{ppm}$. While the content of $\mathrm{Pb}$ on lettuce is not detected.

The presence of pathogenic microbial contaminants and heavy metals in fresh vegetables indicates inadequate handling during planting, harvesting, distribution and transportation to marketing. Traditional market sanitation conditions are generally inadequate, this can be seen from the dirty environment, muddy, unpleasant smell, uncomfortable. This situation allows bacteria to move from one place to antoher or cross contamination (Mujianto, 2008).

Research purposes. Generally, this study aims to assest coliform, E.coli and lead contaminantion in vegetables those are sold at the traditional market in Palembang city.

Hypothesis. The hypothesis of the study was fresh vegetables those sold in traditional marketed in Palembang city contained coliform, E.coli and lead.

\section{METHODS OF RESEARCH}

The Scope of Research. The scope of research was identification of Coliform, E.coli and Lead contamination in fresh vegetables marketed in Palembang city, Indonesia. The execution of research work were four traditional markets which represent marketing area, namely Jakabaring (JK), Perumnas (PM), Alang-Alang Lebar (AAL) and Km 5 (K5).

Random sampling was adopted to collects sample vegetables. There were 27 total samples selected from four traditional markets. The vegetables investigated were lettuce, tomato and carrot as those vegtetables commonly consumed freshly. All research work conducted in treplicate.

Analysis Method. Microbial analysis was determine based on AOAC (1984) method, lead analysis by using AAS (Shimatzu type AA 700). The data were expressed as mean \pm standard deviation was calculated using Microsoft Excel 2007 program.

\section{RESULTS AND DISCUSSION}

Coliform. This research is to know the amount of microbial contamination of pathogenic coliform and E. coli in lettuce, tomatoes, and carrots. Test result showed that coliform contaminants on lettuce, tomatoes, and carrots at the level of traditional market in the city of Palembang ranged from $(9.62 \pm 4.65) \times 10^{2} \mathrm{CFU} / \mathrm{g}$ up to $(10.43 \pm 4.97) \times 10^{2} \mathrm{CFU} / \mathrm{g}$ for lettuce; $(4.73 \pm 1.45) \times 10^{2}$ up to $(5.97 \pm 3.96) \times 10^{2}$ for tomatto; and $(9.13 \pm 5.31) \times 10^{2}$ up to $(13.04 \pm 8.67) \times 10^{2}$ for carrot.

Table 1 - Coliform contamination

\begin{tabular}{lccc}
\hline \multirow{2}{*}{ Traditional Market } & \multicolumn{3}{c}{ Coliform (CFU/g) } \\
\cline { 2 - 4 } & Lettuce & Tomatto & Carrot \\
\hline Jaka Baring & $(10.43 \pm 4.97) \times 10^{2}$ & $(5.38 \pm 2.49) \times 10^{2}$ & $(11.75 \pm 4.32) \times 10^{2}$ \\
Km 5 & $(10.03 \pm 5.03) \times 10^{2}$ & $(4.78 \pm 1.54) \times 10^{2}$ & $(10.68 \pm 4.81) \times 10^{2}$ \\
AAL & $(9.87 \pm 4.91) \times 10^{2}$ & $(5.97 \pm 3.96) \times 10^{2}$ & $(9.13 \pm 5.31) \times 10^{2}$ \\
Perumnas & $(9.62 \pm 4.65) \times 10^{2}$ & $(4.73 \pm 1.45) \times 10^{2}$ & $(13.04 \pm 8.67) \times 10^{2}$ \\
\hline
\end{tabular}

Data were expressed in mean \pm standar deviation based on triplicate readings $(n=3)$.

Based on Table 1, among of the three vegetables, carrot was the most contaminated, followed by lettuce, and tomatoes. Test result also showed that all vegetables involved have level of coliform contamination exeeded the limit of recommended by WHO and the International Commission on Microbiological Specifications for Food i.e. $10-10^{2} \mathrm{CFU} / \mathrm{g}$ (Benti's run et al., 2014). Coliform in vegetables is an indication of contamination that comes from human and animal faecal (Cornish et al., 1999). 
These results correlated with the source of contamination during growth, namely soil, organic fertilizer and water sources (Heaton and Jones, 2008). The carrot is a kind of vegetable that is directly in contact with the ground, lettuce is belong to growing low above the ground while tomatoes are relatively far away from the land where the growing. The application of manure from animal waste, watering with contaminated domestic waste water, post-harvest handling unhygienic by farmers is a potential source of contamination (Chaturvedi et al., 2013; Amoah et al., 2005; Mensah et al., 2002; Halablah et al., 2011; Johannessen et al., 2002). In addition, the use of fresh manure without drying used for vegetable production potentially to produce total coliform fecal matter with a high number of (Drechsel et al., 2000). The presence of coliform is more an indication of the condition of prosessing or inadequate sanitation (anonymous, 2008). But the number of coliform is not necessarily indicates a microbial pathogen (Nguz et al., 2005).

Pathogenic microbial contamination on agricultural products occurs at some point, starting from the production, harvesting, processing, packaging, distribution and marketing in traditional markets (Sapers, 2001). Sanitary condition of traditional market also influences the presence of coliform contamination on vegetables, tomatoes, lettuce and carrots.

Jaka Baring market is a wholesale market that have fair sanitation conditions, where each commodity are separated, and the vegetables are sold in large quantities for retailer. This contrasts with other market such as market Perumnas and $\mathrm{Km} 5$ where vegetables were sold in small quantities and spread on plastic layer on the ground. It is the circumstance which allows the bacteria move from one place to another or cross-contamination (Mujianto, 2008).

In addition the vegetables displayed were often touched by many hands. Handling is often done by hand which is not hygienic are factors that contribute to high levels of microbes. Dusty environment, a lively street, coupled with the quality of the water used to sprinkle vegetables to keep it stay fresh is a supporting factor that can help the survival and multiplication of microorganisms on the surface of vegetables (Chaturvedi et al., 2013).

Escherichia coli. Escherichia coli is one of the members of the coliform group found in human waste. Escherichia coli is often referred as coliform faecal (Fardiaz, 2011). In addition Escherichia coli is one of the microbes used as terms of the quality of microbial impurities contained in the standard specification for horticulture. There are some outbraeks caused by Escherichia coli. Year 2011 poisoning outbreaks occurring caused by E. coli O157: H7 in some States in the United States caused from consuming romaine lettuce. In year 2012, there was a remarkable incident caused by $\mathrm{E}$. coli O157: H7 associated with the consumption of organic spinach, the year 2013 unusual poisoning is also caused by $\mathrm{E}$. coli O157: H7 in ready eat salad, the year 2014 there was outbraek caused by E. coli 0121 on raw clouver sprouts (www.cdc.gov, accessed on September 5, 2016).

Based on the test results analysis, the amount of contaminant Escherichia coli on all vegetable lettuce, tomatoes and carrots marketed in a few traditional in the city of Palembang were $<2$ MPN $/ 100 \mathrm{ml}$. The value of $<2$ MPN (most probable Number) $/ 100 \mathrm{ml}$ indicates that none of the positive test tubes containing Escherichia coli. This mean that all vegetables tested meet the $\mathrm{E}$. coli contamination requirement set by Food and drugs adminstration of Republic Indonesia (2004) which require the limit for Escherichia coli on vegetables are $0-10^{3} \mathrm{CFU} / \mathrm{g}$ (BPOM, 2004).

The levels of $E$ coli on the vegetables is influenced by the location of the cultivation and post-harvest treatment. Most vegetable like lettuce, tomato, and carrot come from area where the water for irrigation during the process of cultivation is derived from well water and rain water. In addition the site of cultivation are no aquaculture enclosures for livestock as source of potential microbial contamination on the vegetables produced. The use of manure derived from chicken manure could be made only at the time of the preparation of the soil prior to planting so as to minimize the occurrence of Escherichia coli contamination.

Escherichia coli in vegetables indicates poor environmental sanitation. Escherichia coli is a bacteria indicator for sanitation. The absence of Escherichia coli on all vegetables tested pointed out that environmental sanitation around the cultivation of market environment classified as good. Vegetables can be contaminated by pathogenic bacteria from 
contaminated irrigation water, soil, sewage or animal waste used as fertilizer. However, postharvest handling like washing with clean water in planting location and sorting by manufacturer, farmer, wholesaler and retailers can reduce pathogenic bacteria, except bacteria spore-forming (Djaafar and Rahayu, 2007).

Soil and water is the habitat of many microbes including Coliform, Ee. coli, S. aureus and Bacillus cereus spore-forming bacteria and (Baird-Parker, 2000). To reduce the occurrence of microbial contamination in vegetable, washing done prior to marketing at the level of farmers and traders in a traditional market.

The traditional market is a great place to meet the seller and the buyer. The building consists of stalls and kiosk, most of which is sold daily necessities. Sanitary condition of traditional markets is generally very bad, it can be seen from the environment is dirty, muddy, smell unpleasant, uncomfortable. It is the circumstance which allows the bacteria move from one place to another or cross-contamination (Mujianto, 2008).

Based on interviews with farmers, the vegetables were cleaned in advance directly after harvest before being sold to wholesaler, including cleaning of residual soil or sand and washing to keep vegetables clean and fresh. Vegetables which have been harvested and collected should be cleaned of all dirt that clings to the surface of the skin, either in the form of dust, splashing on the ground, as well as the remains of the pesticides and fertilizers that is sprayed on leaves when the plant maintenance. The dirt when not cleaned immediately would constitute a source of contamination from a wide range of pathogens that can accelerate damage and lower the quality (Kartasapoetra, 2008).

Heavy metal Lead $(P b)$. Lead contamination in lettuce, tomatoes and carrot can be found in Table 2.

Table 2 - Lead contamination in lettuce, tomatoes and carrot marketed in Palembang city

\begin{tabular}{lccc}
\hline & \multirow{2}{*}{ Market } & \multicolumn{3}{c}{ Lead $(\mathrm{ppb})$} & Carrot \\
\cline { 2 - 4 } & Lettuce & Tomato & $18 \pm 6$ \\
Jaka Baring & $26 \pm 5$ & $11 \pm 2$ & $15 \pm 3$ \\
Km 5 & $25 \pm 5$ & $10 \pm 2$ & $14 \pm 3$ \\
AAL & $21 \pm 6$ & $13 \pm 2$ & $15 \pm 3$ \\
Perumnas & $22 \pm 4$ & $12 \pm 2$ & \\
\hline
\end{tabular}

Data were expressed in mean \pm standard deviation based on triplicate readings $(n=3)$.

Heavy metals lead $(\mathrm{Pb})$ is one of a wide variety of heavy metal pollution in major cities. Heavy metals lead $(\mathrm{Pb})$ goes into the plant through the roots and leaves of the mouth (stomata). Test results showed that lead content on lettuce, tomatoes and carrots were varies in each market. Based on Table 2, lead content $(\mathrm{Pb})$ in lettuce, tomatoes and carrot were below the treshold which specified in the standard heavy metal contamination in foods that is $0.5 \mathrm{ppm}$ (SNI 7387: 2009). Low levels of lead on the vegetables due to land used for cultivation of vegetables are far away from the highway and in addition there was no pesticide used during cultivation. This means that the lead in the vegetables predominantly come from the soil and the plant itself as well as a small portion comes from smoke the rest of the results of fuel combustion in motor vehicles. According to Sari et al. (2011) the lower density of vehicles passing on the road, the lower levels of lead found in the vegetable. Plants contain lead $(\mathrm{Pb})$ fairly high when planted near a highway. This is caused by dust and smoke contamination of vehicle fuel that contains lead.

Pollution of lead $(\mathrm{Pb})$ may occur in the air, water, or soil. Lead $(\mathrm{Pb})$ content in the soil is average of $16 \mathrm{ppm}$, but for certain areas could reach thousands of ppm (Fardiaz, 1992). The concentration of lead $(\mathrm{Pb})$ in a densely populated urban air traffic could be 5 up to 50 times compared with the mountain air (Sunu, 2001). Lead (Pb) content in plants of agricultural or plantation located adjacent to the highway is higher compared to agricultural or plantation located far from the highway. This shows that the pollution of lead $(\mathrm{Pb})$ that potential comes from a motor vehicle. However, in addition to the distance of the plant with the highway, the levels of lead $(\mathrm{Pb})$ in plants are also affected by the traffic density, the time the process of 
planting, the mileage from the location to the area of marketing, the contribution of lead from soil, physiology and morphology of plants and also the direction of the wind.

Lead $(\mathrm{Pb})$ is largely accumulated by plant organ, i.e., leaf, stem, root and root tubers for example carrots. The transfer of lead from soil to plant depending on composition and $\mathrm{pH}$ of soils. High lead concentrations (100 to $1000 \mathrm{mg} / \mathrm{kg}$ ) will lead to toxic influences on the process of photosynthesis and growth. Lead affects only the plant when its concentration is high (Charlena, 2004). The plant can absorb metals $\mathrm{Pb}$ upon condition of fertility and low soil organic matter content. In this situation of heavy metals $\mathrm{Pb}$ will be detached from the bonds of the soil and in the form of ions that move freely in the soil solution. If other metals are not capable of inhibiting its existence, then it will be absorbed by plant roots. Lead is a highly toxic heavy metals, it can be detected in all the inanimate objects in the environment and in the entire biological system. The main source of lead is food and drink. This component is toxic to all aspects of life. Lead showed toxic on the nervous system, hemetologic, hemetotoxic and affect the work of the kidneys.

Lead $(\mathrm{Pb})$ is very dangerous to humans because it is a toxic substances that can not be destroyed or changed in shape. Heavy metals can enter into the environment due to the weathering of rocks containing heavy metals in the ground, the use of natural materials for fertilizers and waste disposal plant and household waste. Heavy metal does not harm the surroundings of life beings but heavy metals harmful when entering into the system the metabolism of living beings in amounts exceeding the threshold.

\section{CONCLUSION}

The results of the study show that there are contaminants coliform in lettuce, tomatoes and carrots on the level of market traders Jaka Baring, Perumnas, Km 5, Alang-Alang Lebar. Highest coliform contaminants found in carrots ranged from $(1304 \pm 8.67) \times 10^{2} \mathrm{CFU} / \mathrm{g}$, followed by lettuce and tomatoes ranged $(10.43 \pm 4.97) \times 10^{2} \mathrm{CFU} / \mathrm{g}$, and tomato $(5.97 \pm 3.96)$ $\times 10^{2} \mathrm{CFU} / \mathrm{g}$. While the contaminant Escherichia coli not found on all vegetable samples test. The highest lead contaminants are present in the lettuce of $26 \pm 5$ ppb followed by carrot $18 \pm 6$ $\mathrm{ppb}$ and tomato $13 \pm 2 \mathrm{ppb}$.

\section{REFERENCES}

1. AdeOluwa, O.O., and Cofie, O. 2012. Urine as an Alternative Fertilizer in Agriculture: Effects in Amaranths (Amaranthus caudatus) Production in Nigeria. Renew. Agric. Food Syst. 27(4):287-294.

2. Amoah, P., Drechsel, P., Abaidoo, C. 2005. Irrigated Urban Vegetables Production in Ghana: Sources of Pathogen Contamination and Health Risk Elimination. Irrig. Drainage 54:49-61.

3. Amoah, P., Drechsel, P., Abaidoo, R,C. 2006. Pesticide and Microbiological Contamination of Vegetables in Ghana's Urban Markets. Arch. Environ. Contam. Toxicol (AECT) 50:1-6.

4. Anonim, 2008. Food Microbiology Testing. InfoPOM.9(2)

5. Food and Drug Supervision Agency. 2004. Regulatory Status of Impurities in Food Products. Food Safety Bulletin, 6. p.4-5.

6. Centers for Disease Control and Prevention (CDC), "Food borne outbreak online database", 2015, http://www.outbreakdatabase. com/details/taco-bell-restaurants-lettuce2006

7. Chaturvedi, M., Kumar, V., Singh, D. and Kumar, S. 2013. Assesment of Microbial Load of Some Common Vegetables Among Two Different Socioeconomic Groups. International Food Research Journal 20(5):2927-2931

8. Cornish, G.A., Mensah, E., Ghesquière, P. 1999. Water Quality and Peri-urban Irrigation. An Assessment of Surface Water Quality for Irrigation and Its Implications for Human Health in the Peri-Urban Zone of Kumasi, Ghana. Report OD/TN 95. HR Wallingford Ltd, Wallingford, UK. 
9. D’Mello, J.P.F., 2003. Food Safety: Contaminants and Toxins. CABI Publishing, Wallingford, Oxon, UK, Cambridge, MA. p. 480

10. De Roever., C. 1999. Microbiological Safety Evaluations and Recommendations on Fresh Produce. Food Control 9:321-347.

11. Djaafar, T.F and Siti Rahayu. 2007. Microbial Impurities on Agrculutural Products, Disease and Prevention. Journal of Agriculutural, 26 (2).

12. Drechsel, P., Abaidoo, R,C., Amoah, P., Cofie, OO. 2000. Increasing Use of Poultry Manure in and Around Kumasi, Ghana: Is Farmers' Race Consumers' Fate. Urban Agric. Mag. 2:25-27.

13. Food and Agriculture Organization (FAO)Morld Health Organization (WHO). 2008. Microbiological Risk Assessment Series: Microbiological Hazards in Fresh Fruit and Vegetables. Available at http://www.who.int/foodsafety

14. Halablab, M, A., Sheet, I.H. and Holail, H,M. 2011. Microbiological Quality of Raw Vegetables Grown in Bekaa Valley, Lebanon. American Journal of Food Technology 6:129-139

15. Heaton, J.C., Jones, K. 2008. Microbial Contamination of Fruit and Vegetables and the Behaviour of Enteropathogens in the Phyllosphere: A Review. J. Appl. Microbiol. 104:613-626.

16. Ignarro, L. J., Balestrieri, M. L., and Napoli, C. 2007. Nutrition, Physical Activity, and Cardiovascular Disease: an Update. Cardiovascular Research, 73(2), 326-340.

17. Johannessen, G.S., Loncarevic, S and Kruse, H. 2002. Bacteriological Analysis of Fresh Produce in Norway. International Journal of Food Microbiology. 77: 199-204.

18. Liu, R. H. 2003. Health Benefits of Fruit and Vegetables are From Additive and Synergistic Combinations of Phytochemicals. American Journal of Clinical Nutrition, 78(3):517-520.

19. Lund, B.M, Baird Parker T.C, Gould G.W. 2000. The Microbiological Safety and Quality of Food. Vol. II. Aspen Publisher, Inc. Gathersburg, Maryland.

20. L. R. Beuchat. 2002. Ecological Factors Influencing Survival and Growth of Human Pathogens on Raw Fruits and Vegetables. Microbes and Infection, 4 (4):413-423

21. Mensah, P., Yeboah-Manu D., Owusu-Darko K. and Ablordey A. 2002. Street Foods in Accra, Ghana: How Safe Are They? Bulletin WHO 80: 546-554.

22. Nguz. K., Shindano, J., Samapundo, S., Huyghebaghebaert, A. 2005. Microbiological Evaluation of Fresh-Cut Organic Vegetables Produced in Zambia. J. Food Contr. 16:623628.

23. Notohadiprawiro, T., 1995. Heavy Metals in Agriculture. Journal of Human and Environment, 2 (7): 3-12.

24. Sapers, G.M. 2001. Efficacy of Washing and Sanitizing Methods for Disinfection of Fresh Fruit and Vegetable Products. Food Technol. Biotechnol. 39(4):305-311.

25. Tambekar, D.H. and Mundhada, R.H. 2006. Bacteriological Quality of Salad Vegetables Sold in Amravati city (India). Journal of Biological Science 6: 28-30.

26. Winarti, $C$ and Miskiyah, 2010. The Status of Contaminants in Vegetables and His Efforts in Indonesia. Journal of Innovation Development of Agriculture. 3(3):227-237.

27. Widaningrum, 2007. The Danger of Contamination of Heavy Metals in Vegetables and Alternative Impurities Prevention. Bulletin.Technology Postharvest. 3, 16-27.

28. Weldezgina. 2016. Bacteriological Contaminants of Some Fresh Vegetables Irrigated with Awetu River in Jimma Town, Southwestern Ethiopia. Research Article. Hindawi Publishing Corporation Advances in Biology Volume 2016, Article ID 1526764, 11 pages

29. Yong, R.N., A.M.O. Mohamed, and S.P. Warkenting 1992. Principles of Contaminant Transport in Soil Development in Geoteknikal Eengineering, 73. Elsevier.

(C) 2017 by the authors. Licensee RJOAS, Orel, Russia. This article is an open access article distributed under the terms and conditions of the Creative Commons Attribution (CC BY) license: http://creativecommons.org/licenses/by/4.0/ 